\title{
Historical Background of Dietary Management For Children with Type 1 Diabetes
}

\author{
Harry Dorchy* \\ Diabetology Clinic, University Children's Hospital Queen Fabiola, Université Libre de Bruxelles, Belgium
}

Submission: January 18, 2018; Published: February 12, 2018

*Corresponding author: Harry Dorchy, Diabetology Clinic, University Children's Hospital Queen Fabiola, Université Libre de Bruxelles, Brussels, 15 avenue JJ Crocq, 1020 Bruxelles, Belgium, Email: hdorchy@ulb.ac.be

\section{Introduction}

\section{The age of dogmatic diets without scientific evidence}

Diet has traditionally played an important role in diabetic therapy. Before the discovery of insulin, a restrictive diet, yielding more or less positive results in $80 \%$ of diabetic subjects, was the only therapy available. Later, it became evident that diet, as such, is the ideal treatment for obese diabetics of middle age (now called type 2 diabetes that is beginning, however, to be encountered in children and adolescents with the rising rate of obesity [1]) since the problem is not based on a lack of insulin. In children and adolescents, diabetes is most often associated with a genetically determined predisposition, the presence of autoimmune markers, aggressive beta-cell destruction leading to severe insulin deficiency (type 1 diabetes), and the urgent need for insulin replacement therapy. Until insulin was made available, a diagnosis of diabetes in children was a death sentence within weeks or months. Many researchers had tried to isolate insulin from animal pancreas. In 1921, the Romanian Nicolae Paulescu, who studied pancreatic secretion in Paris, developed an aqueous pancreatic extract that was injected into a diabetic dog, reducing hyperglycemia and ketonuria. Paulescu published his experience, in perfect French, in the August 1921 issue of the Archives Internationales de Physiologie [2]. In 1922, Canadians Frederick Banting and Charles Best, under the direction of Macleod, with the help of the biochemist James Collip, have prepared clearer insulin free from impurities. This extract was injected successfully to Leonard Thomson, a ketotic diabetic child aged 14 years [3]. He died in 1935. The 1923 Nobel Prize in Physiology and Medicine was attributed to the Canadian team, ignoring the pioneering work of Paulescu.

Over the years, various diets have been proposed often withoutscientific evidence. Restriction in calories, carbohydrates, or lipids was advocated, but also a high intake of the same nutriments or of proteins. "Free diet" as well as "anarchic" eating habits as opposed to "restricted" and "weighed" diets (thanks to a scale or "exchange lists") have been proposed [4,5]. A total caloric restriction inhibits growth and, associated with a lack of insulin, leads to the Mauriac syndrome [6].

One of the main errors was (is!) to speculate that there exists a direct linear correlation between the injection of $x$ units of insulin and the utilization of y grams of glucose [7]. If it was true, one should give more insulin to practice physical activity! In reality, it is the reverse! The reason is that the affinity of the muscular insulin receptors, as well as the activity of GLUT-4, is increased during (and even after) muscular work, but it is not the case for the hepatic insulin receptors. Moreover, the regulation of glucose is dependent on a number of factors such as counter-regulatory hormones, gluconeogenesis, the relative use of glucose and non-esterified fatty acids as energy for muscular exercise, psychological factors (stress), and other mechanisms which are beyond our control $[8,9]$. It has been shown that a decrement in glucose per se or a signal elicited by a moderate decrement in glucose, but largely independent of glucagon and hepatic catecholamine action, stimulates glucose release from the liver during exercise [10].

Alas nowadays carbohydrate counting, even if disputed [11], is still widely used without proving best HbA1c levels [12].

\section{Evolution to a normal and flexible diet}

In the seventies, clinical studies by Henri Lestradet in France [13], and by our group in Belgium [14], have demonstrated that diabetic children, receiving an adequate and flexible dose of insulin according to self monitoring of urine glucose at that time, benefited from a normal "spontaneously balanced and adapted diet". The best glycemic control was not obtained by totally free or rigid diets, but by appropriate daily adjustments of insulin and adequate distribution of normal food intake $[5,12]$. Diabetic children have no fixed energy requirements because they grow and have variable physical activities. Energy intake may fluctuate from day to day without mandatory changes in the need for insulin or in the degree of glycosuria $[13,14]$. To impose 
a weighed and measured diet is undesirable both for diabetic control and for psychological reasons. Moreover, the notion of "measuring" leads to rejection of the entire therapeutic regimen and to emotional problems. A restricted diet that controls only carbohydrate intake and thus favors fat intake is potentially dangerous for the vascular system. On the other hand, even in the seventies we had observed a too high fat consumption in Belgian diabetic children (42.2\% of the total caloric intake) and we had to concentrate our efforts on emphasizing fat rather than carbohydrate restriction [15], which is the case in many industrialyzed countries [5]. We had also noted a positive correlation between the blood levels of $\mathrm{HbA1c}$ and those of total cholesterol and of triglycerides [16], which we confirmed later adding the LDL-cholesterol and apolipoprotein B [17]. There was no relationship between HbA1c and HDL-cholesterol or its subfractions [18]. This was confirmed by other studies [19]. This means that lipid abnormalities are not necessarily related to a diet high in saturated fat, but are certainly related to $\mathrm{HbA1c}$ levels.

Because the multicenter studies of the Hvidoere Study Group, performed in developed countries without financial restriction, show that treatment of childhood diabetes is inadequate in general and that levels of HbA1c are very different, diabetes treatment teams should individually explore the reasons for failure, without any prejudice or bias [12]. Our so-called "recipes" have been published elsewhere [5,12,20].

\section{References}

1. Arslanian S (2002) Type 2 diabetes in children: clinical aspects and risk factors. Horm Res 57 (Suppl 1): 19-28.

2. Paulesco N (1921) Recherche sur le rôle du pancréas dans l'assimilation nutritive. Arch Int Physiol 17: 85-109.

3. Karamitsos DT (2011) The story of insulin discovery. Diabetes Res Clin Pract 93 (Suppl1): S2-S8.

4. Lestradet H (1953) Le problème du régime chez les diabétiques. Evolution des conceptions physiopathologiques. Incidences thérapeutiques. Presse Med 61: 792-796.

5. Dorchy H (2003) Dietary management for children and adolescents with diabetes mellitus; personal experience and recommendations. J Pediatr Endocrinol Metab 16(2): 131-148.

6. Dorchy H, Van Vliet G, Toussain TD, Ketelbant Balasse P, Loeb H (1979) Mauriac syndrome: 3 cases with retinal angiofluorescein study. Diabete
Metab 5(3): 195-200.

7. Sharp A (1999) Nutrition therapy for children and adolescents with diabetes. In: Franz MJ, Bantle JP (Eds.), Medical nutrition therapy for diabetes. American Diabetes Association, Alexandria, Egypt, pp. 211228.

8. Dorchy H, Mozin MJ, Loeb H (1981) Unmeasured diet versus exchange diet in diabetics. Am J Clin Nutr 34(5): 964-965.

9. Dorchy H, Poortmans J (1996) Juvenile diabetes and sports. In: BarOr 0 and the International Olympic Committee (Eds.), The child and adolescent athlete. Oxford, India, p. 10.

10. Cocker RH, Koyama, Y, Denay JC, Camacho RC, Lacy DB, et al. (2002) Prevention of overt hypoglycemia during exercise. Stimulation of endogenous glucose production independent of hepatic catecholamine action and changes in pancreatic hormone concentration. Diabetes 51(5): 1310-1318.

11. Davis NJ, Wylie Rosett J (2008) Death of carbohydrate counting? Diabetes Care 31(7): 1467-1468.

12. Dorchy H (2015) One center in Brussels has consistently had the lowest HbA1c values in the 4 studies (1994-2009) by the Hvidoere International Study Group on Childhood Diabetes: What are the "recipes"? World J Diabetes 6(1): 1-7.

13. Lestradet H, Dartois AM, Machinot S (1974) L'alimentation spontanée de l'enfant et de l'adolescent diabétiques traités par l'insuline. Ann Pediatr 21: 667-676.

14. Dorchy H, Mozin MJ, Smets P, Ernould C, Loeb H (1977) Spontaneous variations in food intake and balance of diabetes. A covariance analysis. Acta Paediatr Belg 30(1): 21-26.

15. Mozin MJ, Dorchy H, de Maertelaer V, Ernould C (1978) Food habits of 215 diabetic children in Belgium. Acta Paediatr Belg 31(1): 56-58.

16. Dorchy H, de Maertelaer V, Toussaint D, Loeb H (1981) Relations entre ingesta lipidiques (cholestérol, graisses saturées et polyinsaturées), cholestérolémie, contrôle métabolique $(\mathrm{HbA1c})$ et rétinopathie des enfants diabétiques. Rev Pediatr 17: 259-270.

17. Willems D, Dorchy H (1990) Taux des lipoprotéines et des apolipoprotéines chez les jeunes diabétiques insulinodépendants. Relations avec l'hémoglobine glycosylée et la fructosamine. Presse Med 19: 17-20.

18. Willems D, Dorchy H (1991) Sous-fractions du HDL-cholestérol chez les jeunes diabétiques insulinodépendants. Press Med 20: 86.

19. Virtanen SM, Rasanen L, Virtanen M, Sippola H, Rilva A, et al (1993) Association of serum lipids with metabolic control and diet in young subjects with insulin-dependent diabetes in Finland. Eur J Clin Nutr 47(2): 141-149.

20. Dorchy H (2010) Treatment management in type 1 diabetes (insulin, diet, sport): “Dorchy's recipes". Rev Med Brux 31 (2 Suppl): S37-S53.

\begin{tabular}{l} 
Your next submission with Juniper Publishers \\
will reach you the below assets \\
- Quality Editorial service \\
- Swift Peer Review \\
- Reprints availability \\
- E-prints Service \\
- Manuscript Podcast for convenient understanding \\
- Global attainment for your research \\
- Manuscript accessibility in different formats \\
( Pdf, E-pub, Full Text, Audio) \\
- Unceasing customer service \\
Track the below URL for one-step submission \\
https://juniperpublishers.com/online-submission.php \\
\hline
\end{tabular}

